\title{
OPTIMASI KADAR B-KAROTEN PADA PROSES PEMBUATAN TEPUNG UBI JALAR ORANYE (Ipomoea batatas (L.) Lam.) DENGAN MENGGUNAKAN RESPONSE SURFACE METHODOLOGY (RSM)
}

\author{
ß-CAROTENE CONTENT OPTIMATION OF ORANGE SWEET POTATO \\ (Ipomoea batatas (L.) Lam.) FLOUR PRODUCTION PROCESS BY \\ RESPONSE SURFACE METHODOLOGY (RSM)
}

\author{
Ir. Bambang Sigit A., M.Si ${ }^{1)}$, Lia Umi Khasanah, ST. MT ${ }^{1)}$, Sri Ruwanti ${ }^{2)}$ \\ ${ }^{1)}$ Staf Pengajar Jurusan Teknologi Hasil Pertanian,Fakultas Pertanian,Universitas Sebelas Maret, Surakarta \\ 2) Mahasiswa Jurusan Teknologi Hasil Pertanian,Fakultas Pertanian,Universitas Sebelas Maret, Surakarta
}

\begin{abstract}
Orange sweet potato has an enormous prospect and opportunity as a food industry basic material. One of sweet potato adequate potention product in industry is sweet potato flour. Sweet potato flour become a precise preference for fulfillment of local basic material. Orange sweet potato flour production will raise the advantage, and also will make it as one of pro vitamin A source, because it has high value of $\beta$-carotene. $\beta$ carotene is damaged easily because of ultra violet ray, heat, sour condition, and air or oxygen contact.

The objective of this reseach was to determine optimal process condition according to $\beta$-carotene damage percentage in orange sweet potato flour production by the influence of drying temperature and time. This research has two factors, they are drying temperature that symbolic as $X_{1}$ variable and drying time as $X_{2}$. Drying temperature $50^{\circ} \mathrm{C}, 60^{\circ} \mathrm{C}$, and $70^{\circ} \mathrm{C}$ were used and drying time were 6,7 , and 8 hours.

The optimation result by Respone Surface Methodology (RSM) showed that optimal process condition in orange sweet potato flour production was $58.067^{\circ} \mathrm{C}$ with drying temperature on 7.0794 hours drying time and resulting $38.4904 \%$ \%-carotene decreased.
\end{abstract}

Key words : $\beta$-carotene, oranye sweet potato, Respone Surface Methodology (RSM)

\begin{abstract}
Abstrak
Ubi jalar oranye memiliki prospek dan peluang yang besar sebagai bahan baku industri pangan. Salah satu bentuk olahan ubi jalar yang cukup potensial dalam kegiatan industri adalah tepung ubi jalar. Tepung ubi jalar dapat menjadi pilihan yang tepat untuk pemenuhan kebutuhan bahan baku berbasis lokal. Pembuatan tepung ubi jalar oranye akan meningkatkan pemanfaatan serta menjadikannya sebagai salah satu sumber provitamin A, karena berpotensial mengandung $\beta$-karoten yang cukup tinggi. $\beta$-karoten memiliki sifat yang mudah rusak karena sinar ultraviolet, panas, kondisi asam serta kontak dengan udara atau oksigen.

Tujuan dari penelitian ini adalah menentukan kondisi proses yang optimum terhadap persentase penurunan kadar ß-karoten pada pembuatan tepung ubi jalar oranye oleh pengaruh suhu dan waktu pengeringan. Penelitian ini menggunakan Response Surface Methodology (RSM). Dalam penelitian ini terdapat dua faktor yaitu suhu pengeringan yang dinyatakan sebagai variabel $\mathrm{X}_{1}$ dan waktu pengeringan sebagai variabel $\mathrm{X}_{2}$. Suhu pengeringan yang digunakan adalah suhu $50^{\circ} \mathrm{C}, 60^{\circ} \mathrm{C}$ dan $70^{\circ} \mathrm{C}$, dan waktu pengeringan yang dilakukan adalah 6,7 , dan 8 jam.

Hasil optimasi menggunakan Response Surface Methodology (RSM) menunjukkan bahwa kondisi proses yang optimal pada pembuatan tepung ubi jalar oranye adalah pada suhu pengeringan $58.067^{\circ} \mathrm{C}$ dengan waktu pengeringan 7.0794 jam dan dihasilkan persentase penurunan kadar ß-karoten yaitu sebesar 38.4904\%.
\end{abstract}

Kata kunci : ß-karoten, Response Surface Methodology (RSM), ubi jalar oranye

\section{PENDAHULUAN}

Ubi jalar memiliki prospek dan peluang yang cukup besar sebagai bahan baku industri pangan. Sebab produktifitas ubi jalar di Indonesia cukup tinggi, selain itu mengandung zat gizi yang berpengaruh positif terhadap kesehatan seperti prebiotik, serat pangan juga antioksidan (antosianin, karotenoid,). Ubi jalar yang daging umbinya berwarna oranye disebabkan oleh adanya zat warna alami yang disebut karotenoid. Kandungan $\beta$-karoten ubi jalar jingga atau oranye yang dilaporkan oleh Hasyim dan Yusuf, (2007), adalah $9900 \mu \mathrm{g} / 100$ gram.(wb) atau (32967 SI).

Penelitian mengenai pembuatan tepung ubi jalar telah banyak dilakukan, terutama ubi jalar putih. Akan tetapi, penelitian tentang pembuatan tepung ubi jalar oranye yang kaya kandungan provitamin A (ß-karoten) sejauh ini belum banyak dilakukan. Pemanfaatan tepung ubi jalar oranye selain bertujuan sebagai bahan pensubstitusi juga dimaksudkan sebagai sumber provitamin A.

Namun karotenoid sendiri memiliki sifat tidak stabil karena mudah teroksidasi oleh adanya 
oksigen serta dapat mengalami isomerisasi bila terkena panas, cahaya, dan asam, akibatnya dapat mengalami penurunan intensitas warna karoten. Sehingga, pada penelitian ini yang menjadi perumusan masalah adalah kondisi proses yang bagaimana (suhu dan waktu pengeringan) yang dapat mengoptimalkan kandungan B-karoten pada tepung ubi jalar oranye yang dihasilkan.

\section{BAHAN DAN METODE}

\section{Bahan}

Bahan utama yang digunakan dalam penelitian ini adalah ubi jalar oranye (Ipomoea batatas L), atau nama lokalnya adalah "Tela Waluh" yang memiliki ciri-ciri umum: warna daging umbi jingga kemerah-merahan (oranye), dan warna kulit merah campur oranye. Ubi jalar diperoleh langsung dari petani ubi jalar di Tawangmangu. Bahan untuk analisa adalah aseton, petroleum eter, alumina aktif, natrium sulfat $\left(\mathrm{Na}_{2} \mathrm{SO}_{4}\right)$ anhidrous, aquades, dan $\beta$ karoten murni.

\section{Proses pendahuluan}

Ubi jalar segar dikupas, selama pengupasan ubi jalar yang telah dikupas direndam dalam air bersih untuk mengurangi terjadinya pencoklatan, dicuci bersih, diiris dengan ketebalan $\pm 2 \mathrm{~mm}$, diblansir dengan cara mencelupkannya dalam air panas suhu $90{ }^{\circ} \mathrm{C}$ selama 30 detik.

\section{Proses pengeringan}

Proses pengeringan dilakukan dengan menggunakan cabinet dryer. Suhu pengering yang digunakan yaitu suhu $50{ }^{\circ} \mathrm{C}, 60{ }^{\circ} \mathrm{C}$, dan 70 ${ }^{\circ} \mathrm{C}$. Hal ini didasarkan pada Karrer dan Jucker (1950) dalam Wijayanti (2003), yang menyatakan bahwa ß-karoten akan rusak pada suhu di atas 60 ${ }^{\circ} \mathrm{C}$. Waktu pengeringan didasarkan pada kadar air maksimal dimana chip masih bisa digiling. Berdasarkan hasil penelitian pendahuluan, dengan ketebalan irisan ubi jalar oranye $\pm 2 \mathrm{~mm}$ dan lama pengeringan 8 jam diperoleh kadar air chip yaitu $\pm 9 \%$. Berdasarkan hasil tersebut maka waktu pengeringan yang digunakan antara lain 6 jam, 7 jam, dan 8 jam.

\section{Pembuatan tepung ubi jalar oranye}

Dapat dilihat pada gambar 1 .

\section{Metode Analisis}

Analisis kandungan ß-karoten dilakukan pada ubi jalar segar dan tepung ubi jalar oranye dengan menggunakan spektrofotometri (metode Carr Price dalam Anton Apriyantono, dkk. 1989). Analisa kadar air dengan metode
Thermogravimetri (AOAC, 1970, Ragana, 1979 dalam Slamet Sudarmadji, dkk. 1997).

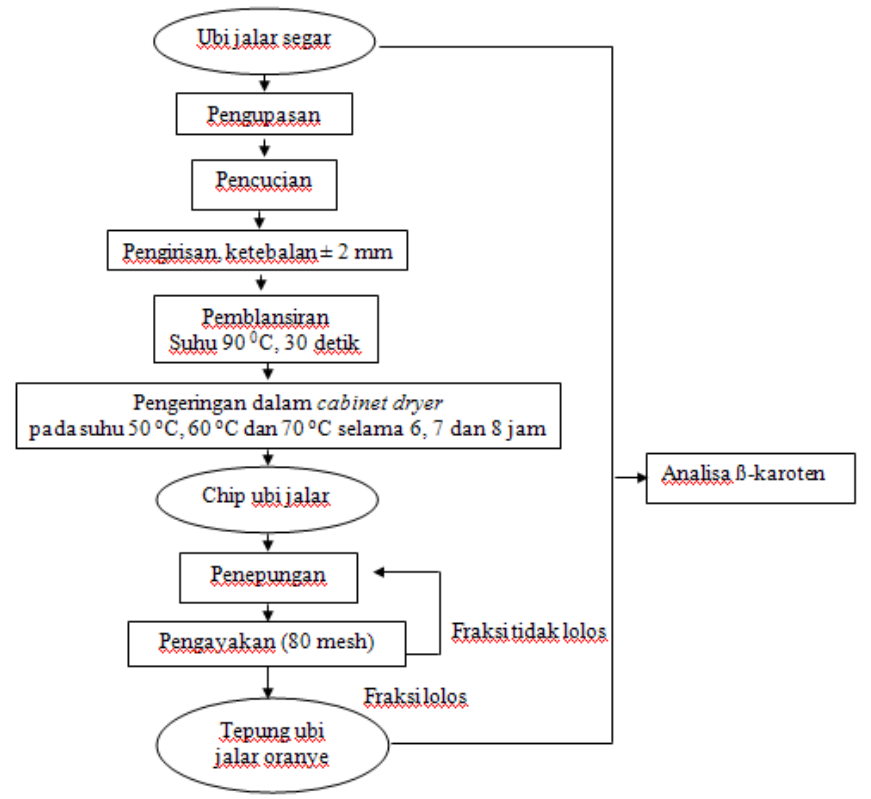

Gambar 1 Diagram Batang Prosentase Penurunan Kadar $\beta$-karoten pada berbagai Suhu dan Waktu Pengeringan

\section{Rancangan Percobaan}

Penelitian ini menggunakan Response Surface Methodology (RSM). Dalam penelitian ini terdapat dua faktor yaitu suhu pengeringan yang dinyatakan sebagai variabel $\mathrm{X}_{1}$ dan waktu pengeringan sebagai variabel $X_{2}$. Suhu pengeringan yang digunakan adalah suhu $50{ }^{\circ} \mathrm{C}$, $60{ }^{\circ} \mathrm{C}$ dan $70{ }^{\circ} \mathrm{C}$, dan waktu pengeringan yang dilakukan adalah 6, 7, dan 8 jam. Kombinasi RSM untuk kode dan tak kode disajikan pada Tabel 1.

Tabel 1. Kode dan Tak Kode untuk Kombinasi RSM

\begin{tabular}{lccc|lccc}
\hline \multicolumn{2}{r|}{$\mathrm{X}_{1}$ (suhu pengeringan) } & \multicolumn{4}{|c}{$\begin{array}{c}\mathrm{X}_{2} \text { (waktu } \\
\text { pengeringan) }\end{array}$} \\
\hline Kode & -1 & 0 & 1 & Kode & -1 & 0 & 1 \\
Tak & 50 & 60 & 70 & Tak & 6 & 7 & 8 \\
kode & & & & kode & & & \\
$\left({ }^{\circ} \mathrm{C}\right)$ & & & (jam) & & \\
\hline \hline
\end{tabular}

$$
\begin{array}{ll}
\text { Keterangan: } & -1: \text { Nilai variabel terendah } \\
& 0: \text { nilai variabel medium } \\
& 1: \text { nilai variabel tertinggi }
\end{array}
$$

Penelitian ini, dilakukan dua kali ulangan perlakuan dan dua kali ulangan analisa terhadap kadar B-karoten, sehingga dihasilkan 36 kombinasi RSM dalam kode antara $\mathrm{X}_{1}$ dan $\mathrm{X}_{2}$. Kombinasi RSM dalam kode disajikan pada Tabel 2.

\section{Analisis Data}

Data yang diperoleh kemudian dianalisis dengan metode RSM (Response Surface Methodology) menggunakan software Matlab 7.0. 
Tabel 2. Kombinasi RSM dalam Kode

\begin{tabular}{|c|c|c|c|c|c|}
\hline No. & $\begin{array}{c}\mathrm{X}_{1} \text { (suhu) } \\
\mathrm{OC}\end{array}$ & $\begin{array}{c}\mathrm{X}_{2} \text { (waktu) } \\
\text { jam }\end{array}$ & No. & $\begin{array}{c}\mathrm{X}_{1} \text { (suhu) } \\
\mathrm{OC}\end{array}$ & $\begin{array}{c}\mathrm{X}_{2} \text { (waktu) } \\
\text { jam }\end{array}$ \\
\hline 1. & -1 & -1 & 19. & $\overline{\bar{c}}$ & 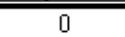 \\
\hline 2 . & -1 & -1 & 20 . & 0 & 0 \\
\hline 3. & -1 & -1 & 21. & 1 & 0 \\
\hline 4. & -1 & -1 & 22 . & 1 & 0 \\
\hline 5. & 0 & -1 & 23. & 1 & 0 \\
\hline 6. & 0 & -1 & 24. & 1 & 0 \\
\hline 7. & 0 & -1 & 25 & -1 & 1 \\
\hline 8. & 0 & -1 & 26 . & -1 & 1 \\
\hline 9. & 1 & -1 & 27 . & -1 & 1 \\
\hline 10. & 1 & -1 & 28 & -1 & 1 \\
\hline 11. & 1 & -1 & 29. & 0 & 1 \\
\hline 12. & 1 & -1 & 30. & 0 & 1 \\
\hline 13. & -1 & 0 & 31. & 0 & 1 \\
\hline 14. & -1 & 0 & 32. & 0 & 1 \\
\hline 15. & -1 & 0 & 33. & 1 & 1 \\
\hline 16. & -1 & 0 & 34. & 1 & 1 \\
\hline 17. & 0 & 0 & 35. & 1 & 1 \\
\hline 18. & 0 & 0 & 36. & 1 & 1 \\
\hline & nn & $\begin{array}{l}\text {-1) }: \text { Nil } \\
0): \text { nila } \\
\text { 1) }: \text { nila }\end{array}$ & aria & $\begin{array}{l}\text { erendah } \\
\text { eedium } \\
\text { ertinggi }\end{array}$ & \\
\hline
\end{tabular}

\section{HASIL DAN PEMBAHASAN}

Ubi jalar yang digunakan dalam penelitian ini adalah ubi jalar berjenis oranye yang berasal dari Tawangmangu. Hasil analisa terhadap kadar air dan kadar ß-karoten pada ubi jalar segar dan tepung ubi jalar oranye dengan variasi suhu dan waktu pengeringan disajikan pada Tabel 3 .

Dari Tabel 3 dapat diketahui bahwa kandungan $\beta$-karoten ubi jalar segar oranye yang berasal dari Tawangmangu berkisar antara 1521.15-2716.24 $\mu \mathrm{g} / 100 \mathrm{~g}$ (wb). Nilai tersebut masuk dalam kisaran kadar B-karoten ubi jalar oranye pada penelitian Anonymous (2006) dan Cordell (2005) dalam Nareswari, dkk. (2006), yang berkisar antara 225,56 sampai $8509 \mu \mathrm{g} / 100 \mathrm{~g}$ (wb) maupun hasil penelitian menurut Hasyim dan Yusuf yaitu $9900 \mu \mathrm{g} / 100 \mathrm{~g}$ (wb).

Betakaroten merupakan salah satu unsur pokok dalam bahan pangan yang mempunyai peranan sangat penting, yaitu memberikan kontribusi terhadap warna bahan pangan (warna oranye) dan juga nilai gizi sebagai provitamin A (Goldman et al, 1983 dalam Histifarina, dkk. 2004). Herastuti, dkk. (1993) dalam Histifarina, dkk. (2004), menjelaskan bahwa proses pengeringan dan penepungan mengakibatkan penurunan kadar $\alpha$ dan $\beta$-karoten. Selain itu, mutu produk yang dikeringkan juga dipengaruhi oleh suhu dan waktu pengeringan.

Perbedaan suhu dan waktu pengeringan akan berpengaruh terhadap kadar air bahan. Semakin tinggi temperatur pada proses pengeringan, maka kadar air akan semakin kecil (Istadi, dkk. 2002). Dari Tabel 3 dapat dilihat bahwa semakin tinggi suhu pengeringan dan semakin lama waktu pengeringan, maka kadar air tepung ubi jalar oranye semakin menurun. Pada pengeringan dengan suhu $50{ }^{\circ} \mathrm{C}$ dan waktu pengeringan 6 jam menujukkan kadar air yang paling tinggi yaitu berkisar antara 9.05-10.44\%. Sedangkan proses pengeringan dengan suhu 70 ${ }^{\circ} \mathrm{C}$ selama 8 jam memiliki kadar air yang paling rendah yaitu berkisar antara 5.10-6.86\%.

Kadar B-karoten mengalami penurunan setelah dibuat tepung, penurunan kadar ß-karoten dapat dilihat dengan membandingkan antara ubi jalar segar (db) dengan tepung ubi jalar $(\mathrm{db})$ Penurunan kadar ß-karoten ini terjadi pada masing-masing suhu baik pada suhu $50{ }^{\circ} \mathrm{C}, 60{ }^{\circ} \mathrm{C}$ maupun suhu $70{ }^{\circ} \mathrm{C}$. Untuk dapat mengetahui seberapa besar prosentase penurunan kadar Bkaroten dengan adanya interaksi antara suhu dan waktu pengeringan, maka dapat dilihat pada Tabel 4.

Dari Tabel 4 dapat diketahui bahwa prosentase penurunan kadar $\beta$-karoten berkisar antara $21.37 \%$ sampai $65.15 \%$. Prosentase penurunan kadar $\beta$-karoten pada penelitian ini masih berada dibawah dari penelitian yang telah dilakukan oleh Herastuti (1981) dalam Setyabudi (1994), yang melaporkan bahwa kerusakan Bkaroten karena proses penepungan sebesar $67 \%$.

Gambar 2 menunjukkan prosentase penurunan kadar ß-karoten dari ubi jalar oranye segar menjadi tepung.

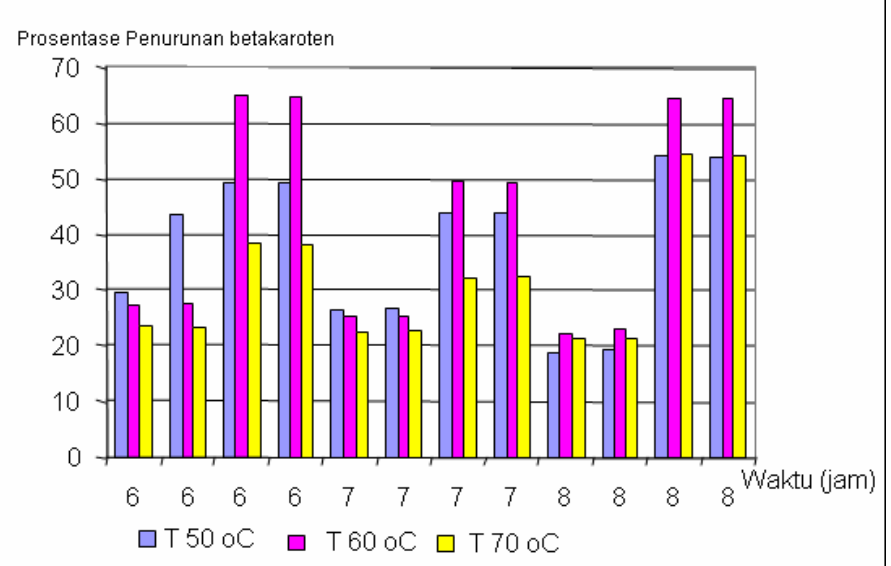

Gambar 2 Diagram Batang Prosentase Penurunan Kadar B-karoten pada berbagai Suhu dan Waktu Pengeringan

Dari Gambar 4.1 dapat dilihat bahwa prosentase penurunan kadar $\beta$-karoten yang paling tinggi terjadi pada suhu $60{ }^{\circ} \mathrm{C}$. Kerusakan B-karoten selama pembuatan tepung ubi jalar oranye merupakan sesuatu hal yang sulit dikendalikan. Karoten memiliki sifat yang sangat rentan terhadap oksigen, panas, cahaya serta tidak stabil pada kondisi asam (Gredory, 1996 dalam Legowo, 2005). Selama proses pengeringan, panas yang mengalir pada bahan akan mendegradasi karoten. Menurut Karrer dan Jucker (1950) dalam Setyabudi (1994), degradasi thermal karoten menyebabkan pemutusan rantai 
Tabel 3. Kadar Air dan Kadar ß-karoten Ubi Jalar Segar dan Tepung Ubi Jalar Oranye

\begin{tabular}{|c|c|c|c|c|c|c|c|c|c|c|c|c|}
\hline \multirow{3}{*}{ Sampel } & \multicolumn{12}{|c|}{ Suhu pergeringan $\left(\mathrm{T}^{\circ} \mathrm{C}\right)$ dan Waktu pengeringan (jam) } \\
\hline & \multicolumn{4}{|c|}{$50^{\circ} \mathrm{C}$} & \multicolumn{4}{|c|}{$60^{\circ} \mathrm{C}$} & \multicolumn{4}{|c|}{$70^{\circ} \mathrm{C}$} \\
\hline & 0 jam & 6 jam & 7 jam & 8 jam & 0 jam & 6 jam & ? jam & 8 jam & 0 jam & 6 jam & ? jam & 8 jam \\
\hline \multicolumn{13}{|l|}{ Kadar air \% (wb) } \\
\hline $\mathrm{R} 1(1)$ & 71.11 & 9.05 & 8.93 & 8.45 & 71.87 & 7.67 & 6.38 & 6.20 & $71.6 ?$ & 6.68 & 6.40 & 6.10 \\
\hline R1 (2) & 70.58 & 9.06 & 8.87 & 8.38 & 71.89 & 7.72 & 6.20 & 6.13 & 71.68 & 6.80 & 6.33 & 5.10 \\
\hline $\mathrm{R} 2(1)$ & 72.26 & 10.37 & 9.77 & 8.94 & 71.88 & 8.46 & 8.35 & 7.31 & 71.77 & 7.51 & 7.15 & 6.86 \\
\hline R2 (2) & 72.02 & 10.44 & 9.80 & 8.98 & 71.54 & 8.53 & 8.50 & 7.35 & 71.67 & 7.67 & 7.16 & 6.83 \\
\hline \multicolumn{13}{|l|}{$\begin{array}{c}\text { Kadar ß-karoten } \\
\mu g / 100 \mathrm{~g}(\mathrm{w} b)\end{array}$} \\
\hline R1 (1) & 2267.84 & 4996.11 & 5211.41 & 5790.06 & 2155.41 & 5138.23 & 5378.75 & 5600.60 & 2228.88 & 5602.22 & 5698.26 & 5811.01 \\
\hline R1 (2) & 2273.44 & 4007.57 & 5190.79 & 5770.87 & 2160.64 & 5117.06 & 5378.75 & 5621.84 & 2228.88 & 5622.76 & 5698.26 & 5831.56 \\
\hline $\mathrm{R} 2(1)$ & 2699.64 & 4401.79 & 4913.69 & 4043.64 & 2710.63 & 3074.45 & 4451.15 & 3159.82 & 1518.13 & 3071.19 & 3387.48 & 2282.82 \\
\hline R2(2) & 2710.81 & 4417.99 & 4929.87 & 4071.42 & 2721.85 & 3088.98 & 4480.66 & 3172.32 & 1524.16 & 3082.14 & 3375.01 & 2293.60 \\
\hline \multicolumn{13}{|l|}{$\begin{array}{c}\text { Kadar ß-karoten } \\
\mu g / 100 \mathrm{~g}(\mathrm{db})\end{array}$} \\
\hline R1 (1) & 7850.73 & 5493.07 & 5722.49 & 6324.22 & 7663.85 & 5564.79 & 5745.29 & 5970.86 & 7869.01 & 6003.55 & 6088.17 & 6188.44 \\
\hline $\mathrm{R} 1(2)$ & 7717.94 & 4406.87 & 5696.16 & 6298.79 & 7688.34 & 5545.30 & 5734.37 & 5989.13 & 7872.15 & 6032.93 & 6083.23 & 6203.57 \\
\hline R2 (1) & 9732.12 & 4911.31 & 5445.55 & 4440.71 & 9639.05 & 3358.77 & 4856.52 & 3408.92 & 5378.71 & 3320.42 & 3648.51 & 2450.90 \\
\hline $\mathrm{R} 2(2)$ & 9690.95 & 4933.02 & 5465.75 & 4473.18 & 9639.37 & 3377.10 & 4896.78 & 3424.14 & 5381.12 & 3338.28 & 3635.39 & 2461.72 \\
\hline
\end{tabular}

Keterangan: R1) ulangan perlakuan 1, R2) ulangan perlakuan 2.; (1) ulangan analisis 1. (2) ulangan analisis 2

karoten yang akan merusak karoten, sehingga intensitas warna karoten menjadi menurun. Dengan demikian, kadar ß-karoten pun juga akan menurun.

Adanya oksigen bebas yang kontak dengan irisan ubi jalar oranye selama proses pengeringan dapat menurunkan intensitas warna dari chip yang dihasilkan. Sebab didalam ubi jalar terdapat senyawa yang menyebakan terjadinya reaksi pencoklatan (browning). Menurut Onwueme (1978) dalam Ginting (2006), pada ubi jalar terdapat senyawa yang tidak berbahaya bagi kesehatan tetapi dapat mempengaruhi mutu dari ubi jalar itu sendiri. Senyawa tersebut berupa ipomeaemarone, furanoterpen, koumarin dan polifenol yang terbentuk di dalam jaringan pada saat ubi jalar terluka atau dikupas saat pengolahan karena kontak dengan oksigen. Selain menimbulkan rasa pahit, senyawa polifenol khususnya juga dapat menyebabkan warna umbi menjadi gelap atau coklat yang dapat terikut pada produk akhirnya.

Dengan demikian, semakin besar luas permukaan umbi maka kemampuan untuk kontak dengan oksigen akan semakin besar, sehingga kemampuan untuk terjadi browning juga semakin besar, terjadinya reaksi ini akan dipercepat oleh adanya panas. Irisan umbi didalam cabinet dryer, sedikit banyak terjadi kontak dengan oksigen bebas, dengan adanya panas dari alat pengering maka irisan umbi akan mudah terjadi pencoklatan. Meskipun didalam penelitian ini telah dilakukan blanching untuk mengurangi aktivitas enzim maupun senyawa-senyawa yang terdapat pada ubi jalar oranye, namun sedikit masih terjadi pencoklatan pada chip yang dihasilkan.
Faktor lain yang menyebabkan penurunan kadar ß-karoten pada pembuatan tepung ubi jalar oranye adalah proses penepungan. Pada proses penepungan, terjadi gesekan yang terus-menerus antara partikel-partikel tepung ubi jalar oranye dengan dinding mesin penepung sehingga menghasilkan panas yang cukup besar. Selama proses penggilingan juga terjadi kontak dengan oksigen yang tidak dapat dihindarkan keberadaanya.

Untuk mengetahui kondisi proses yang optimum terhadap prosentase penurunan kadar Bkaroten tepung ubi jalar oranye, pada penelitian ini digunakan Metode Permukaan Respon (Response Rurface Methodology). Pada penelitian ini, digunakan 2 faktor yaitu suhu pengeringan dan waktu pengeringan. Suhu pengeringan dinyatakan sebagai variabel $X_{1}$ dan waktu pengeringan sebagai variabel $\mathrm{X}_{2}$. Dari masingmasing variabel $\mathrm{X}$, ditentukan titik minimum (titik medium) sebagai titik tengah tak kode kemudian ditentukan titik bawah tak kode dan titik atas tak kode berupa titik-titik dibawah dan diatas titik tengah dengan interval yang sama dalam satu variabel. Pada penelitian ini interval untuk $X_{1}$ adalah 10 , sebab $X_{1}$ (suhu pengeringan) terdiri dari suhu $50{ }^{\circ} \mathrm{C}, \quad 60{ }^{\circ} \mathrm{C}$ dan $70{ }^{\circ} \mathrm{C}$ sedangkan interval untuk $\mathrm{X}_{2}$ adalah 1 , sebab $\mathrm{X}_{2}$ (waktu pengeringan) yang digunakan antara lain 6 , 7, dan 8 jam. Variabel $\mathrm{X}_{1}$ (suhu pengeringan), suhu $60{ }^{\circ} \mathrm{C}$ merupakan titik minimum sebagai titik tengah tak kode, sedangkan suhu $50{ }^{\circ} \mathrm{C}$ sebagai titik bawah kode dan suhu $70{ }^{\circ} \mathrm{C}$ sebagai titik atas tak kode. Untuk variabel $\mathrm{X}_{2}$ (waktu pengeringan), yang menjadi titik minimum sebagai titik tengah tak kode adalah waktu pengeringan $7 \mathrm{jam}$, sedangkan waktu pengeringan 
Tabel 4. Prosentase Penurunan ß-karoten dari Ubi Jalar Segar menjadi Tepung

\begin{tabular}{cccccccccc}
\hline \hline \multirow{2}{*}{ Sampel } & \multicolumn{9}{c}{ Suhu pengeringan $\left(\mathrm{T}^{\circ} \mathrm{C}\right)$ dan waktu pengeringan (jam) } \\
\cline { 2 - 10 } & \multicolumn{3}{c}{$50{ }^{\circ} \mathrm{C}$} & \multicolumn{3}{c}{$60{ }^{\circ} \mathrm{C}$} & \multicolumn{3}{c}{$70{ }^{\circ} \mathrm{C}$} \\
\cline { 2 - 10 } & 6 jam & 7 jam & 8 jam & 6 jam & 7 jam & 8 jam & 6 jam & 7 jam & 8 jam \\
\hline \hline a. R1 (1) & 29.43 & 26.49 & 18.76 & 27.51 & 25.15 & 22.21 & 23.72 & 22.65 & 21.37 \\
b. R1 (2) & 43.39 & 26.83 & 19.08 & 27.76 & 25.30 & 22.98 & 23.35 & 22.71 & 21.18 \\
c. R2 (1) & 49.43 & 43.93 & 54.27 & 65.15 & 49.61 & 64.63 & 38.28 & 32.18 & 54.44 \\
d. R2 (2) & 49.20 & 43.72 & 53.94 & 64.96 & 49.19 & 64.47 & 37.95 & 32.43 & 54.24 \\
\hline \hline
\end{tabular}

Keterangan: R1) ulangan perlakuan 1, R2) ulangan perlakuan 2

(1) ulangan analisa 1, (2) ulangan analisa 2

\begin{tabular}{|c|c|c|c|c|c|c|}
\hline No. & $\begin{array}{c}\mathrm{X}_{1} \\
\text { (suhu) } \\
{ }^{C} \\
\end{array}$ & $\begin{array}{c}\mathrm{X}_{2} \\
\text { (waktu) } \\
\text { jam }\end{array}$ & No. & $\begin{array}{c}\mathrm{X}_{1} \\
\text { (suhu) } \\
\circ \mathrm{C} \\
\end{array}$ & $\begin{array}{c}\mathrm{X}_{2} \\
\text { (waktu) } \\
\text { jam } \\
\end{array}$ & $\begin{array}{c}\mathrm{Y} \\
\% \text { penurunan } \\
\text { B-karoten } \\
\end{array}$ \\
\hline 1. & -1 & -1 & 1. & 50 & 6 & 29.43 \\
\hline 2. & -1 & -1 & 2. & 50 & 6 & 43.39 \\
\hline 3. & -1 & -1 & 3. & so & 6 & 49.43 \\
\hline 4. & -1 & -1 & 4. & so & 6 & 49.20 \\
\hline 5. & 0 & -1 & 5. & 60 & 6 & 2751 \\
\hline 6. & 0 & -1 & 6. & 60 & 6 & 27.76 \\
\hline 7. & 0 & -1 & 7. & 60 & 6 & 65.15 \\
\hline 8. & 0 & -1 & 8. & 60 & 6 & 6496 \\
\hline 9. & 1 & -1 & 9. & 70 & 6 & 23.72 \\
\hline 10. & 1 & -1 & 10. & $\pi 0$ & 6 & 2335 \\
\hline 11. & 1 & -1 & 11. & $\pi 0$ & 6 & 38.28 \\
\hline 12. & $i$ & -1 & 12. & 70 & 6 & 3795 \\
\hline 13. & -1 & 0 & 13. & so & 7 & 26.49 \\
\hline 14. & -1 & 0 & 14. & 50 & 7 & 26.83 \\
\hline 15. & -1 & 0 & 15 & 50 & 7 & 4393 \\
\hline 16. & -1 & 0 & 16. & 50 & 3 & 43.72 \\
\hline 17. & 0 & 0 & 17. & 60 & 7 & 25.15 \\
\hline 18. & 0 & 0 & 18. & 60 & $?$ & 2530 \\
\hline 19. & 0 & 0 & 19. & 60 & 7 & 49.61 \\
\hline 20. & 0 & 0 & 20 & 60 & 7 & 49.19 \\
\hline 21. & 1 & 0 & 21. & $\pi 0$ & 7 & 22.65 \\
\hline 22. & 1 & 0 & 22. & 70 & 7 & 22.71 \\
\hline 23. & 1 & 0 & 23. & 70 & 7 & 32.18 \\
\hline 24. & 1 & 0 & 24. & 70 & 7 & 32.43 \\
\hline 25. & -1 & 1 & 25 & 50 & 8 & 18.76 \\
\hline 26. & -1 & 1 & 26. & so & 8 & 19.08 \\
\hline 27. & -1 & 1 & 27. & so & 8 & 5427 \\
\hline 28. & -1 & $i$ & 28. & 50 & 8 & 5394 \\
\hline 29. & 0 & 1 & 29. & 60 & 8 & 22.21 \\
\hline 30. & 0 & 1 & 30. & 60 & 8 & 22.98 \\
\hline 31. & 0 & 1 & 31. & 60 & 8 & 64.63 \\
\hline 32. & 0 & $i$ & 32. & 60 & 8 & 64.47 \\
\hline 33. & 1 & $i$ & 33. & 70 & 8 & 2137 \\
\hline 34. & 1 & $i$ & 34. & $\pi 0$ & 8 & 21.18 \\
\hline 35. & $i$ & 1 & 35. & $\pi 0$ & 8 & 54.44 \\
\hline 36. & 1 & 1 & 36. & $x 0$ & 8 & 54.24 \\
\hline
\end{tabular}

6 jam sebagai titik bawah kode dan waktu pengeringan 8 jam sebagai titik atas tak kode. Kemudian dibuat 36 kombinasi RSM (secara kode) antara variabel $\mathrm{X}_{1}$ dan $\mathrm{X}_{2}$, sebab pada penelitian ini dilakukan 2 kali ulangan perlakuan dan 2 kali ulangan analisa. Kombinasi RSM dalam kode disajikan pada Tabel 5. Kemudian melakukan eksperimen terhadap 36 kombinasi RSM (secara tak kode) dari Tabel 5 tersebut. Hasil eksperimen yang diperoleh disajikan pada Tabel 6.
Pada penelitian ini digunakan RSM berorde dua sehingga harus dicari nilai $X_{1}^{2}$ yang berasal dari masing-masing nilai $X_{1}$, dan nilai $X_{2}^{2}$ yang berasal dari masing-masing nilai $\mathrm{X}_{2}$. Untuk bisa mencari masing-masing nilai $X_{1}^{2}$ maupun $X_{2}^{2}$, terlebih dahulu harus dicari nilai C-nya yaitu dengan rumus seperti dibawah ini:

$$
C=\frac{\sum_{i=1}^{m} x_{1}^{2}}{M}=\frac{-1^{2}+-1^{2}+\ldots .+1^{2}}{36}=\frac{2}{3}\left(\operatorname{untuk} X_{1}^{2}\right)
$$




$$
C=\frac{\sum_{i=1}^{m} x_{2}^{2}}{M}=\frac{-1^{2}+-1^{2}+\ldots .+1^{2}}{36}=\frac{2}{3}\left(\text { untuk } X_{2}^{2}\right)
$$

Setelah didapatkan nilai $\mathrm{C}$, untuk mengisi kolom $X_{1}^{2}$ yaitu dengan cara menguadratkan masing-masing nilai $X_{1}$ lalu dikurangkan dengan $\mathrm{C}$, begitu juga untuk mengisi kolom $X_{2}^{2}$, masingmasing nilai $X_{2}$ dikuadratkan dan dikurangkan dengan nilai $\mathrm{C}$, seperti berikut ini:
i) $-1^{2}-\frac{2}{3}=\frac{2}{3}$
ii) $0^{2}-\frac{2}{3}=-\frac{2}{3}$

Sedangkan untuk mengisi kolom dengan variabel $\mathrm{X}_{1} \mathrm{X}_{2}$, maka tinggal mengalikan masingmasing nilai pada kolom $X_{1}$ dengan masingmasing nilai pada kolom $X_{2}$. Dari semua perhitungan tersebut dapat ditabulasikan pada Tabel 6. Selanjutnya dilakukan fitting respon dengan langkah-langkah sebagai berikut:

1) Membuat matrik $X$ berukuran $36 \times 6$ dan matrik $\mathrm{Y}$ berukuran $36 \times 1$. Matrik X berukuran $36 \times 6$ diatas, selanjutnya dibuat transpose matrik $\mathrm{X}$ atau $\left(X^{\prime}\right)$

2) Mengalikan transpose dari matrik $X$ dengan matrik $X \quad\left(X^{\prime} X\right)$

3) Mengalikan matrik $X^{\prime}$ dengan matrik $Y$

4) Mencari nilai b melalui persamaan $\left(X X^{\prime}\right)=b\left(X^{\prime} Y\right)$, maka $\quad b=\left(X X^{\prime}\right)^{-1}\left(X^{\prime} Y\right)$ sehingga didapatkan nilai $b$

5) Setelah didapatkan nilai b, maka masingmasing nilai $b$ dimasukkan dalam fungsi respon yaitu seperti dibawah ini:

$$
\begin{aligned}
Y & =b_{0}+b_{1} X_{1}+b_{n} X_{n}+b_{11} X_{1}^{2}+\ldots . \\
& +b_{n n}{ }_{n}^{2}+b_{12} X_{1} X_{2}+\ldots+b_{n-1 . n}{ }_{n-1} X_{n} \\
Y & =37.5525-3.0821_{X 1}-0.3567 X 2 \\
& -7.2862 X 1^{2}+6.3050{ }^{2} 2^{2}+3.3331_{X 1 X 2}
\end{aligned}
$$

Karena nilai $\mathrm{C}$ yang telah diperoleh adalah $2 / 3$, maka nilai $b_{0}$ menjadi:

$$
\begin{aligned}
b_{0} & =37.5525-[2 / 3(-7.2862)]-[2 / 3(6.3050)] \\
& =38.20663
\end{aligned}
$$

Sehingga fungsi responnya menjadi:

$$
\begin{aligned}
Y & =38.20663-3.0821_{X 1}-0.3567 X 2 \\
& -7.2862 X 1^{2}+6.3050 x 2^{2}+3.3331^{2} X 1 X 2
\end{aligned}
$$

6) Untuk mengetahui bentuk fungsi respon yang diperoleh pada poin nomer 5 diatas, maka terlebih dahulu menghitung nilai eigen value dari $\lambda_{1}$ dan $\lambda_{2}$ $\left|\begin{array}{ll}b_{11}-\lambda & 1 / 2 b_{12} \\ 1 / 2 b_{12} & b_{22}-\lambda\end{array}\right|=0$

$$
\begin{aligned}
& \left|\begin{array}{cc}
-7.2862-\lambda & 1 / 2(3.3331) \\
1 / 2(3.3331) & 6.3050-\lambda
\end{array}\right|=0 \\
& \lambda^{2}+0.9812 \lambda-48.71688=0 \\
& \lambda_{12}=\frac{-b \pm \sqrt{b^{2}-4 a c}}{2 a} \\
& \lambda_{12}=\frac{-(0.9812) \pm \sqrt{0.9812^{2}-4.1(-48.71688)}}{2.1} \\
& \lambda_{1}=-7.4876 \quad \lambda_{2}=6.5064
\end{aligned}
$$

Karena $\lambda_{1}$ dan $\lambda_{2}$ positif, maka gambar responnya berbentuk sadel seperti yang terlihat pada Gambar 3, sedangkan untuk melihat kedalam bentuk contour dapat dilihat pada Gambar 4.

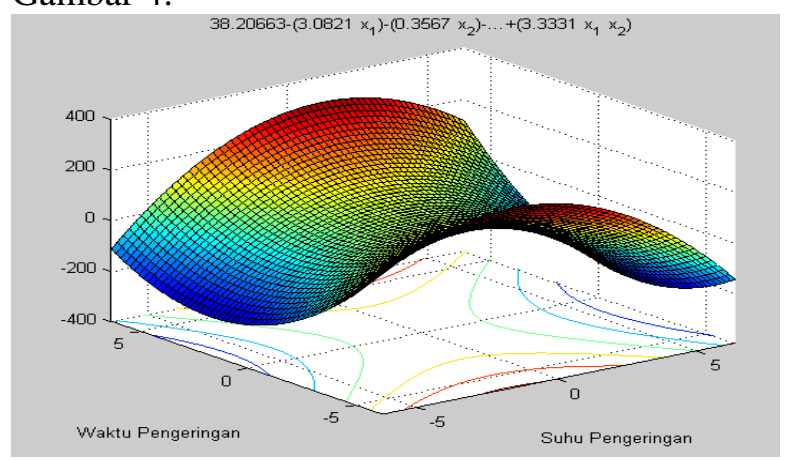

Gambar 3. Surface Contour plot

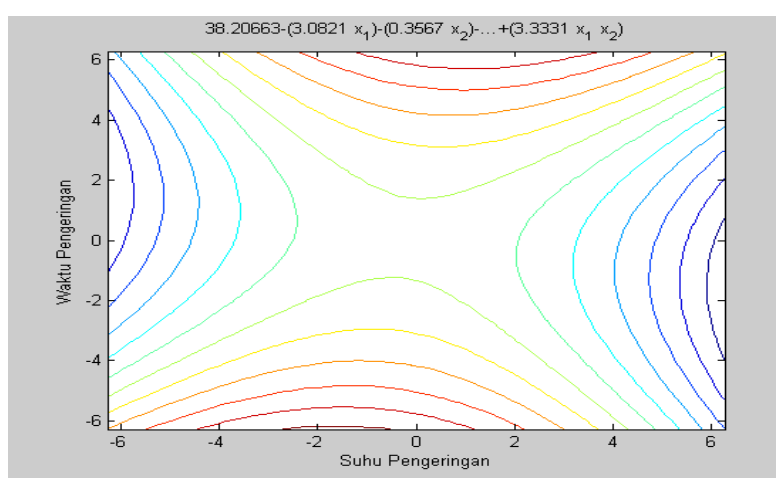

Gambar 4. Contour plot

7) Untuk mencari titik stasioner dari gambar respon tersebut diatas, maka dengan mencari nilai $\mathrm{X}_{1}$ dan $\mathrm{X}_{2}$ dari persamaan fungsi respon dibawah ini:

$$
\begin{aligned}
Y= & 38.20663-3.0821_{X 1}^{-0.3567} X 2^{-} \\
& 7.2862{ }^{2}+6.3050{ }^{2} 2^{2}+3.3331^{-} X 1 X 2
\end{aligned}
$$

Berdasarkan persamaan respon tersebut, maka nilai $\mathrm{X}_{1}$ dan $\mathrm{X}_{2}$ dicari dengan penurunan fungsi terhadap $\mathrm{X}_{1}$ dan $\mathrm{X}_{2}$ berikut ini: 
Tabel 6. Tabulasi Nilai dari masing-masing Variabel

\begin{tabular}{|c|c|c|c|c|c|c|c|}
\hline No. & $B_{0} \%$ & $X_{1}$ & $X_{2}$ & $X_{1}^{2}$ & $X_{2}^{2}$ & $X_{1} X_{2}$ & $\mathrm{Y}$ \\
\hline 1. & 1 & -1 & -1 & $1 / 3$ & $1 / 3$ & 1 & 29.43 \\
\hline 2. & 1 & -1 & -1 & $1 / 3$ & $1 / 3$ & 1 & 43.39 \\
\hline 3 & 1 & -1 & -1 & $1 / 3$ & $1 / 3$ & 1 & 49.43 \\
\hline 4. & 1 & -1 & -1 & $1 / 3$ & $1 / 3$ & 1 & 49.20 \\
\hline 5. & 1 & 0 & -1 & $-2 / 3$ & $1 / 3$ & 0 & 27.51 \\
\hline 6. & 1 & 0 & -1 & $-2 / 3$ & $1 / 3$ & 0 & 27.76 \\
\hline 7. & 1 & 0 & -1 & $-2 / 3$ & $1 / 3$ & 0 & 65.15 \\
\hline 8. & 1 & 0 & -1 & $-2 / 3$ & $1 / 3$ & 0 & 64.96 \\
\hline 9. & 1 & 1 & -1 & $1 / 3$ & $1 / 3$ & -1 & 23.72 \\
\hline 10. & 1 & 1 & -1 & $1 / 3$ & $1 / 3$ & -1 & 23.35 \\
\hline 11. & 1 & 1 & -1 & $1 / 3$ & $1 / 3$ & -1 & 38.28 \\
\hline 12. & 1 & 1 & -1 & $1 / 3$ & $1 / 3$ & -1 & 37.95 \\
\hline 13. & 1 & -1 & 0 & $1 / 3$ & $-2 / 3$ & 0 & 26.49 \\
\hline 14. & 1 & -1 & 0 & $1 / 3$ & $-2 / 3$ & 0 & 26.83 \\
\hline 15. & 1 & -1 & 0 & $1 / 3$ & $-2 / 3$ & 0 & 43.93 \\
\hline 16. & 1 & -1 & 0 & $1 / 3$ & $-2 / 3$ & 0 & 43.72 \\
\hline 17. & 1 & 0 & 0 & $-2 / 3$ & $-2 / 3$ & 0 & 25.15 \\
\hline 18. & 1 & 0 & 0 & $-2 / 3$ & $-2 / 3$ & 0 & 25.30 \\
\hline 19. & 1 & 0 & 0 & $-2 / 3$ & $-2 / 3$ & 0 & 49.61 \\
\hline 20. & 1 & 0 & 0 & $-2 / 3$ & $-2 / 3$ & 0 & 49.19 \\
\hline 21. & 1 & 1 & 0 & $1 / 3$ & $-2 / 3$ & 0 & 22.65 \\
\hline 22. & 1 & 1 & 0 & $1 / 3$ & $-2 / 3$ & 0 & 22.71 \\
\hline 23. & 1 & 1 & 0 & $1 / 3$ & $-2 / 3$ & 0 & 32.18 \\
\hline 24. & 1 & 1 & 0 & $1 / 3$ & $-2 / 3$ & 0 & 32.43 \\
\hline 25. & 1 & -1 & 1 & $1 / 3$ & $1 / 3$ & -1 & 18.76 \\
\hline 26. & 1 & -1 & 1 & $1 / 3$ & $1 / 3$ & -1 & 19.08 \\
\hline 27. & 1 & -1 & 1 & $1 / 3$ & $1 / 3$ & -1 & 54.27 \\
\hline 28. & 1 & -1 & 1 & $1 / 3$ & $1 / 3$ & -1 & 53.94 \\
\hline 29. & 1 & 0 & 1 & $-2 / 3$ & $1 / 3$ & 0 & 22.21 \\
\hline 30. & 1 & 0 & 1 & $-2 / 3$ & $1 / 3$ & 0 & 22.98 \\
\hline 31. & 1 & 0 & 1 & $-2 / 3$ & $1 / 3$ & 0 & 64.63 \\
\hline 32. & 1 & 0 & 1 & $-2 / 3$ & $1 / 3$ & 0 & 64.47 \\
\hline 33. & 1 & 1 & 1 & $1 / 3$ & $1 / 3$ & 1 & 21.37 \\
\hline 34. & 1 & 1 & 1 & $1 / 3$ & $1 / 3$ & 1 & 21.18 \\
\hline 35. & 1 & 1 & 1 & $1 / 3$ & $1 / 3$ & 1 & 54.44 \\
\hline 36. & 1 & 1 & 1 & $1 / 3$ & $1 / 3$ & 1 & 54.24 \\
\hline
\end{tabular}

Keterangan: ${ }^{\text {*) }} \mathrm{B}_{0}$ selalu diisi 1

$$
\begin{aligned}
& \frac{d Y}{d X_{1}}=-3.0821-14.5724 X_{1}+3.3331 X_{2}=0 \\
& \frac{d Y}{d X_{2}}=-0.3567+12.61 X_{2}+3.3331 X_{2}=0
\end{aligned}
$$

Dari kedua persamaan tersebut diperoleh $\mathrm{X}_{1}=-0.1933, \mathrm{X}_{2}=0.0794$

Selanjutnya nilai $\mathrm{X}_{1}$ dan $\mathrm{X}_{2}$ disubstitusikan kedalam persamaan respon, sehingga diperoleh nilai $Y$.

$$
\begin{aligned}
Y= & 38.20663-3.0821(-0.1933)- \\
& 0.3567(0.0794)-7.2854\left(-0.1933^{2}\right)+ \\
& 6.3046\left(0.0794^{2}\right)+3.3331(-0.1933)(0.0794) \\
= & 38.4904
\end{aligned}
$$

Dengan demikian, titik stasioner dari fungsi respon bentuk sadel tersebut adalah (38.4904; $-0.1933 ; 0.0794)$

8) Setelah didapatkan kode $X_{1}=-0.1933$, $X_{2}=0.0794$ dan $Y=38.4904$, maka dapat dicari suhu dan waktu pengeringan yang optimal dengan cara interpolasi linear. Dari hasil perhitungan $X_{1}=-0.1933$ diinterpolasi menjadi $58.067{ }^{\circ} \mathrm{C}$ dan untuk $X_{2}=0.0794$ diinterpolasi menjadi 7.0794 jam.

Dengan demikian, kondisi proses yang optimal pada pembuatan tepung ubi jalar oranye adalah pada suhu pengeringan 58.067 ${ }^{\circ} \mathrm{C}$ dengan waktu pengeringan 7.0794 jam. Untuk menghasilkan prosentase penurunan kadar ß-karoten yaitu sebesar $38.4904 \%$. 


\section{KESIMPULAN DAN SARAN}

\section{Kesimpulan}

Hasil dari penelitian ini menunjukkan bahwa dengan menggunakan Response Surface Methodology (RSM), kondisi optimum pada pembuatan tepung ubi jalar oranye adalah pada suhu pengeringan $58.067{ }^{\circ} \mathrm{C}$ dan waktu pengeringan 7.0794 jam, dengan dihasilkan prosentase penurunan kadar $\beta$-karoten yaitu sebesar $38.4904 \%$.

\section{Saran}

Saran yang dapat diberikan dalam penelitian ini yaitu perlu dilakukan penelitian lebih lanjut mengenai sifat fisika dan kimiawi tepung ubi jalar oranye pada kondisi proses optimum yaitu pada suhu pengeringan $58{ }^{\circ} \mathrm{C}$ dengan waktu pengeringan 7 jam.

\section{DAFTAR PUSTAKA}

Anonim. 2004. Wortel tak hanya Atasi Sakit Mata.

http://cybermed.cbn.net.id/cbprtl/common/pto friend.asp $\mathrm{x}$. $\mathrm{x}=$ Natural+Healing. (diakses tanggal 29 Desember 2009).

Anonim. 2009. Tabloid Agrina. http://www.agrina-

online.com/show article.php. (diakses tanggal 31 Maret 2009).

Antarlina, S.S. dan J.S. Utomo. 1999. Proses Pembuatan dan Penggunaan Tepung Ubijalar untuk Produksi Pangan. Balitkapi No. 15: 3044.

Apriyantono, Anton, dkk. 1989. Analisis Pangan. PAU Pangan dan Gizi. IPB

Dwiyanto, Kusuma dan Bambang Setiadi. 2008. Plasma Nutfah dalam Pengelolaan Pemanfaatan dan Pelestarian Sumberdaya Genetik Pertanian. http://tasklist.blogspot.com/2008 0501 archive.html (diakses tanggal 5 Juli 2009).

Ginting, Erliana et al. 2006. Teknologi Pasca Panen Ubi Jalar Mendukung Diversifikasi Pangan Dan Pengembangan Agroindustri. Balitkapi. Malang. Bul. Palawija No. 11: 1528.

Hasyim, Ashol dan M. Yusuf. 2008. Diversifikasi Produk Ubi Jalar sebagai Bahan Pangan Substitusi Beras. Badan Litbang Pertanian, Malang. Tabloid Sinar Tani, 30 Juli 2008.

Histifarina, D., D. Musaddad, dan E. Murtiningsih. 2004. Teknik Pengeringan dalam Oven untuk Irisan Wortel Kering Bermutu. Balai Penelitian Tanaman Sayuran.
Jurnal Hortikultura 14(2):107-112Silalahi, Jansen. 2006. Makanan Fungsional. Kanisius. Yogyakarta.

Istadi, dkk. 2002. Konstanta Pengeringan Dalam Sistem Pengeringan Lapis Tipis (Thin Layer Drying). Prosiding Seminar Nasional Teknologi Proses Kimia. UNDIP Semarang.

Legowo, Antono. 2005. Pengaruh Blanching terhadap Sifat Sensoris dan Kadar Provitamin Tepung Labu Kuning. Skripsi. Fakultas Teknologi Pertanian Universitas Gadjah Mada Yogyakarta.

Nuryanti dan Djati H Salimy. 2009. Metode Permukaan Respon dan Aplikasinya pada Optimasi Eksperimen Kimia. Pusat Pengembangan Energi Nuklir. Batan. Risalah Lokakarya Komputasi dalam Sains dan Teknologi Nuklir: 6-7 Agustus 2008 (373391).

Rukmini, S. dkk. 1985. Stabilitas Provitamin A dalam Pembuatan Tepung Wortel (Daucus Carota L.). Nomor 1 tahun ke-8. Forum Pasca Sarjana. IPB. Bogor.

Setyabudi, M. Irawan.1994. Potensi Tepung Wortel sebagai Sumber B-karoten dan Pewarna Alami Pada Geplak. Skripsi. Fakultas Teknologi Pertanian Universitas Gadjah Mada Yogyakarta.

Santosa, dkk. 2002. Penggunaan Response Surface Methodology untuk Optimasi Proses Dekafeinasi Menggunakan Kitosan dari Kulit Udang. Jurnal Teknologi Industri Pangan Vol. XIII No.1.

Silalahi, Jansen. 2006. Makanan Fungsional. Kanisius. Yogyakarta.

Sudarmadji, Slamet, Bambang Haryono dan Suhardi. 1989. Analisa Bahan Makanan dan Pertanian. PAU Pangan dan Gizi UGM. Yogyakarta.

Wijayanti, Heri. 2003. Forfifikasi B-karoten Buah Labu Kuning (Cucurbita maxima) pada Pembuatan Kue Wingko. Skripsi. Fakultas Teknologi Pertanian Universitas Gadjah Mada Yogyakarta.

Yudawati, Ari. 2004. Ekstraksi Karoteid Ubi Jalar (Ipomoea batatas L.): Pengaruh Ukuran Partikel Tepung Ubi Jalar terhadap Efisiensi Ekstraksi Karotenoid. Skripsi. Fakultas Teknologi Pertanian Universitas Gadjah Mada Yogyakarta.

Zuraida, Nani dan Yati Supriyati. 2001. Usaha tani Ubi Jalar sebagai bahan Pangan Alternatif dan Diversifikasi Sumber Karbohidrat. Balai Penelitian Bioteknologi Tanaman pangan, Bogor. Bulletin Agro-Bio, 4(1):13-23. 